\title{
Empowerment of Women's Defense Disability (Speech impaired) in Bengkala Village Kecamatan Kubutambahan Kabupaten Buleleng, Bali
}

\author{
Pande Wayan Renawati ${ }^{*}$ \\ ${ }^{1}$ Universitas Hindu Negeri IGB Sugriwa Denpasar-Indonesia \\ \{panderena@gmail.com ${ }^{1}$ \}
}

\begin{abstract}
Every human being has shortcomings and weaknesses, when combined into a capable strength in developing ideas and ideas. The lives of people with disabilities / Speech impaired, especially women in Bengkala Village, Kubutambahan District, Buleleng Regency, basically have a zest for life, if not directed, their talents will automatically be hidden. The method used is a qualitative method. The uniqueness of the people with disabilities / Speech impaired, tips for empowerment through understanding the Speech impaired language, compassion, warmth and a sense of brotherhood among the residents. Furthermore, the types of activities developed and their impact on residents with disabilities / Speech impaired in Bengkala Village, Buleleng Regency, through massage, yoga, weaving and cooking exercises with the aim of having a sense of concern for oneself and understanding others they face. In addition, through yoga practice for Speech impaired women are able to refrain from their emotions and egos, so that their lives are efficient and effective, and benefit society.
\end{abstract}

Keywords: Empowerment of Women; People with Disabilities; Speech impaired.

\section{Introduction}

Every person in this life has advantages and disadvantages, which of course are attached to each of them. It is real and has become a powerful will as a natural balance. Both in nature and its contents in this world is called Bhuwana Agung and in nature that exists in humans itself is called Bhuwana Alit. Broadly speaking, the existence of shortcomings and strengths that will actually cover up or will complement a hidden power behind it. However, what becomes a concern if the advantages are among people with disabilities or deaf mute who are often referred to as Speech impaired. These people with disabilities cannot hear and cannot speak. However, it has a characteristic that distinguishes it from other normal people in the area, namely in Bengkala Village, Kubutambahan District, Buleleng Regency. The number of Speech impaired residents in the village is around 48, both men and women. The Speech impaired residents, especially men, work as traders, farmers, carpenters, masons, and even install water pipes on the edge of ravines in Bengkala Village.

In this regard, Speech impaired women also do not remain silent. Some sell food, some help their husbands in the garden, and take other activities that support the family. These Speech impaired women really need to be considered, especially when they look weak due to the imbalance of the body situation they have experienced since birth and the various 
obstacles they face in family and community life. Based on this background, there are several problems which are discussed as follows. (1). How is the uniqueness of the Speech impaired residents in Bengkala Village in their daily life? (2). How are the empowerment tips for women with disabilities / Speech impaired in Bengkala Village, Buleleng Regency? (3). Types of empowerment and its impact on women with disabilities / Speech impaired in Bengkala Village, Buleleng Regency?

\section{Result and Discussion}

The Uniqueness of the lives of Residents with Disabilities / Speech impaired in Bengkala Village, Kubutambahan District, Buleleng.

The life of people in this world must have their own uniqueness which will be a memory during their lifetime. This uniqueness also occurs in this Speech impaired resident in Bengkala Village. One of the causes is heredity and association. Because the offspring is certain, but if it is due to association, it is because after the Speech impaired's child is born they are also raised in a family with a Speech impaired disability so that the offspring becomes disabilities / Speech impaired, but if raised in a normal person, it will usually be normal because they are always trained to speak and heard by who took care of him since childhood. According to Foster and Anderson [1] [2] stated that:

One of the causes of hearing impairment and speech impairment is the personalistic system. As a system, illness (illness) is caused by the intervention of an active agent, which can be supernatural beings (supernatural beings or gods), non-human beings (ghosts, ancestral spirits or evil spirits) or human beings (sorcerers or sorcerers). sorcerer). The sick person is the victim, the object of aggression or punishment directed specifically at him for reasons specific to him alone.

This has become the belief of the local population and a belief so that it continues to grow without a deadline for completion. Along with that it was also attempted to heal in several ways. There is also a way to sound the song after being born. If the child turns around, it is declared normal, otherwise it is declared speech impaired. In this regard, the form of healing according to Pelly [1] [2] states that:

The form of healing is carried out through traditional health in various forms of

ceremonies or rituals, gamelan / traditional music accompaniment, dances, singing,

trance, use of mantras, giving talisman or healing which is done by massaging or

massaging body parts and various types of medicinal ingredients. and various taboos.

These healing efforts have become a tradition in all regions in Bali, but all return to the results of past human actions that are experienced in the present. In connection with this, the daily activities of the speech impaired people are diligent in carrying out their activities and cannot be separated from the servants when they attend the Village Temple, Puseh Temple and Dalem Temple in the field of temple cleanliness and the distribution of lawar (Balinese food made from jackfruit, papaya as well). Anointed long beans and filled with pork or chicken or without meat and so on with their distinctive seasoning too. The food in the form of lawar was divided in two for the Speech impaired's residents and other villagers.

In addition, the speech impairments residents are also used as grave diggers. As a grave digger for one body he was paid Rp. 250,000, -. The funds are not immediately divided between diggers, but they collect up to 6 Balinese months or 7 Indonesian calendar months, because the calculation of 1 Balinese month is $7 \times 5=35$ days. \& it symbolizes of Sapta wara 
(days of the week) and panca wara, namely umanis, pahing, pon, wage, kliwon) after which some pigs are bought to be slaughtered and the meat is distributed as diggers, totaling 6 people evenly. Other people with speech impairments also work as village parking fee collectors, as pecalang 2 people, as construction workers, as wood censors for those who have wood chopping machines.

Another thing that is stated as unique in Bengkala Village is that there are different things in terms of the holy days of Purnama and Tilem. The difference is when in Bali, in general, they carry out the ceremony for the purnama or full moon as well as during Tilem or the dead moon on that day, but especially for Bengkala Village, it is the next day. It is quite unique that its history is still being traced. In addition, the history of Bengkala Village that [3]:

Based on the inscription, Bengkala Village was founded in the month of Crawana or July Saka 1103.So according to calculations at that time it was July 22, 1181, the leader at that time was Sri Maha Raja Haji Jaya Pangus who was assisted by his two wives, namely: 1. Sri Pameswari Sri Indra Lancana 2. Sri Maha Raja Dewi Sri Sasangkaja Ketana.

The village in the inscription is Village or now it is called Desa Krama, Desa Adat Bengkala. Regarding the area of Desa Krama or Desa Adat Bengkala before 1079 AD, Desa Pakwan or now called Desa Pakisan, was still controlled by Desa Krama or Desa Adat Bengkala. Furthermore, in 1079-1088 AD Desa Krama or Desa Adat Bengkala because there were enough people in Desa Pakwan or Desa Pakisan, and it was proven until now that Desa Pakwan or Desa Pakisan Banjar Kelandis existed in a village called Dewa Bengkala.

Based on the Bengkala Village Inscription, every July 22 each year is celebrated as the day of the founding of the Bengkala Village and is celebrated with great enthusiasm by showing the works of art from all members of the community which are assembled with dance performances until the evening. In this connection, the results of the author's research according to Renawati (2018: 51) as a tribute to the Bengkala women are as follows:

In Bengkala there is a beautiful girl named Ratu Ayu Mas Merenteng who is always looking for by Ratu Bagus Makletug when she is sick with goiter. Because she didn't want to be married, Ratu Ayu fled through Tukad Air Raya / Tukad Gelung until she met Ratu Kubayan who led a boarding house in Dukuh Pasek. Ratu Ayu remained there and did not marry until the end of her life. Every time she visits Ratu Ayu to Bengkala, Ratu Bagus always brings a beautiful stone. After adding up the stones, the number is the same as the pelinggih at Pura Pucak Gelung in Klandis. There is also Ratu Ayu Mas there. Since then, Bengkala and Klandis have been enemies. After 2016 the Village of Klandis - Bengkala was harmonious again until now. From the Bengkala and Klandis story, until now the Majuk - jukan tradition is celebrated during Pengerupukan before Nyepi Day. By capturing a woman who is characterized by a simple character with her allure, long hair, genuine, impeccable and pretty polite to be captured by 8 women while all dressed in traditional clothes gathering at the Pura Desa / Bale Agung The beautiful woman was arrested with the preparation of 8 men as executors from a few days earlier. Furthermore, the procession is carried around the Bale Agung Temple. Meanwhile, 5 people at the jaba Pura Bale Agung prayed and performed Nyepi renewal. This Majuk-jukan tradition is carried out to respect / honor women and is not easy to be harassed. This tradition has been carried out since ancient times and does not mention the number of years. The point is, since the lamp days there has been respect for women in Bengkala Village.

Until now, respect for the women in the village is still carried out in their daily life. By not taking the workload so hard, only the partner is busy working. For this reason, even though 
you are a homebody, there should be activities that can increase the income for the residents, especially women. That is a glimpse of some of the uniqueness of Bengkala Village to know more deeply.

\section{Empowerment Tips for Women with Disabilities / Speech Impaired in Bengkala Village, Buleleng Regency.}

Before discussing tips for empowering people with disabilities, it is necessary to know the sad situation they feel on a daily basis. If we see someone who is easily emotional, likes to be alone, with a blank look, is depressed either because of his soul or his economic situation. Of course, with this condition, it is necessary to help the servants who understand the social spirit of these Speech Impaired people. According to [4], the information regarding the sadness of persons with disabilities is as follows:

Persons with disabilities no longer have to constantly be trapped in an atmosphere of prolonged grief. Recognition of the rights of persons with disabilities is an important resource that can be used to improve the morale of persons with disabilities and thereby increase the chances of success in leading a meaningful personal and social life.

Before taking further steps to provide empowerment for women with disabilities / speech impaired, there are a number of tips to be followed through understanding the souls of these people with speech impairments. It needs to be understood through a psychological approach. According to [5] it is mentioned that: Psychology is a discipline that studies human mentality, thoughts and behavior more deeply. This discipline examines the flow of human thought and the reasons behind these behaviors and actions. Psychology is often used to solve problems or find the right solution in a complex series of human activities. From the health side too, psychological problems or personality-related disorders can arise due to certain disease conditions. This also applies to the opposite, some human behavior can also affect health. Therefore, understanding more deeply about psychology is an important thing to do to achieve mental health and overall well-being.

The woman with hearing impairment is very sensitive in spirit, so she really needs attention from those around her, to make her more advanced in living her life. The opinions of experts implied in the article for the disabled / speech impaired are as follows, according to [6] mentioned that:

Integrating women and girls with disabilities. But most women with disabilities cannot live like others. They are morelikely to: $\quad$ be extremely poor $\bullet$ have little or no schooling • be without vocational skills $\bullet$ be unemployed $\bullet$ have less access to public services $\bullet$ be unmarried or childless $\bullet$ be physically, asexually, or psychologically abused.They make up, without doubt, one of the most excluded and isolatedgroups of people in every society, being triply disadvantaged by theirdisabilities, by their sex, and by poverty.Women with disabilities are disadvantaged by negativeattitudes towards disability.Like all other disabled people, women with disabilities are often treatedas if their particular disability has affected all their other abilities. In society'seyes they are not capable of earning an income, let alone of living independently.

So the understanding above shows that people with disabilities are considered by most people to be unable to be independent, in fact they have a lot of potential and can be developed in them. As in Bengkala Village, residents with disabilities when visited before were indeed very poor, lacking education, marginalized, their views were far from purposeful, but after the Flipmas Indonesia visit with funding from Pertamina's CSR, the disabled people 
with disabilities began to enthusiastically make themselves independent even in the process. There are things like competition between the speech impaired and the normal people there. For example, people with disabilities / speech impairments start studying at Inclusive Primary Schools so that both male and female people with hearing impairment participate in learning at the school and get diplomas and knowledge on how to read and write, so that with technological developments nowadays, speech impaired citizens can do WhatsApp through Anderoid cellphones and almost all have them even though they use Indonesian in reverse arrangement, but the reader understands the meaning and gives an appropriate answer, for example: Have you eaten? But on their WhatsApp, the speech impaired residents ask, Did you eat? Even so, it has become progress for him and follows the flow of modern technology at this time. However, there are some things below as tips before giving empowerment to speech impaired persons, especially women in Bengkala Village, as follows:

- Comprehension of speech impaired Language

One of the problems in providing knowledge to people with disabilities is related to language barriers. Because basically the speech deaf language there with the speech impaired language in other places, of course the meaning is different. In this connection there is an opinion from [7] which is stated as follows:

"Disability is part of the human experience, but sometimes people use words or phrases that are insensitive and do not promote understanding, dignity, and respect for people with disabilities. More often than not, this is not intentional, but can be hurtful just the same. Learn how to communicate with and about people with disabilities using people-first language and other helpful tips."

As an instructor, they must also learn and understand gestures of body language or code from the hands of these speech impaired people. Basically, it is not easy to understand, to be attentive and remember the meaning of each movement of body language of the speech impaired people which has a different meaning. Incidentally, there is a character who is fluent in the language of speech impaired persons whose name is I Ketut Kanta. Through him all the ways to understand the gestures of the speech impaired people can be understood its meaning.

- Be Compassionate

The word "compassion" according to https://nusadaily.com/opinion/welas-asih-suatuekspresi-kepedulian-terhadap-sesama.html states that. The sense of brotherhood (paseduluran) is an internal driving force to care (empathy) for other people or parties who are considered siblings. According to [8] it is mentioned that:

"Women with disabilities face significantly more difficulties - in both public and private spheres - in attaining access to adequate housing, health, education, vocational training and employment, and are more likely to be institutionalized. They also experience inequality in hiring, promotion rates and pay for equal work, access to training and retraining, credit and other productive resources, and rarely participate in economic decision making."

When dealing with speech impaired people who are faced with these difficulties, then through a compassionate attitude that does not differentiate between others is very important in dealing with it. When you cannot be present in the middle of your life, you will miss the presence of those who always give you love. However, if he is present, he considers the person who is most needed in his life. But when he leaves, he will miss his presence again via WhatsApp to contact him to ask about his return. There lies the happiness of a person who gives him a sense of compassion for the community, especially the women.

- Be Friendly 
To approach the people with speech impairment should be friendly. Even though he did not understand sign language, a smile was acceptable to him. But if you can make him laugh it is very helpful in developing his soul. Because, according to [9] it is stated that Sloka Manawa Dharmasastra III, 57 states that.

"Cocanti jamayo yatra

winacatyacu tatkulam

na cocanti to yatraita

wardhate taddhi sarwada"

With a meaning Where the women live in sorrow, the family will quickly break down, but where that woman does not suffer, the family will always be happy.

The sloka above reflects that a woman, especially with a disability, should certainly receive protection and be maintained in a happy state, not even sadness that approaches her life. Because with sadness, the family will quickly break down. To get rid of sadness, expression is needed, it takes effort to make people around him happy with all the efforts he can do.

- Be Full of Brotherhood

Related to the sense of brotherhood, in RgVeda X.191 sloka 2 and 3 states that:

"Sam gacchadhvam sam vadadhvamsam vo Manamsi janatam/deva bhagam yatha

purveSamjanana upasate."

"Samano mantrah samitih samanisamanam Manah saha cittam esam Samanam

Mantram Abhi mantreyah samanena vo havisa juhomi."

With meaning 'O people, walk, talk together and think in the same direction As the gods used to divide their duties, that is how you should exercise your rights, "Come together to think toward the same goal, as I have outlined Match your heart and unite your thoughts, so that you can achieve the goal of living together and happily.

Through the sloka above, it is expected that there will be an agreement for everything to run on the basis of thought and discussion with a common goal of gaining mutual happiness among the people with disabilities / speech impaired. In addition to the above, the speech impaired community is very happy if they are considered as brothers, because by involving themselves as siblings, the people with hearing impairment are more free to confide in their hearts to people they trust in holding secrets.

\section{Types of Empowerment and Their Impact on Disabilities / Speech Impaired in Bengkala Village, Buleleng.}

- Types of Empowerment for Disabilities in Bengkala Village, Buleleng.

Since long ago, the life of the speech impaired community, especially the women, was used to weaving activities, but because a lot of capital was needed and there was no place to distribute their work, it had been a long time since it was not continued. Recently, since the collaboration between lecturers who are members of Flipmas Ngayah Bali and Pertamina, the lecturers have started to develop their thoughts according to their hobbies and scientific disciplines. There are those who develop their farms, plantations, others who develop painting, dance, yoga, weaving, making ingka, making incense to frying peas, making cassava chips and making ladrang chips and making jamu turmeric. Because in the Bengkala village, according to its history in the past until now, there are many native Bengkala turmeric which tastes different from other village turmeric in Bali.

In connection with yoga, which is very necessary for speech impaired residents to calm themselves down, a yoga movement is created for the elderly and people with speech impairments in Bengkala Village. The uniqueness experienced as mentioned above has never 
planned a yoga movement, but guidance is obtained for this movement to make the speech impaired people more confident and make them more confident that life can make him happy with the yoga movement, so that he can find calm and peace in his heart.

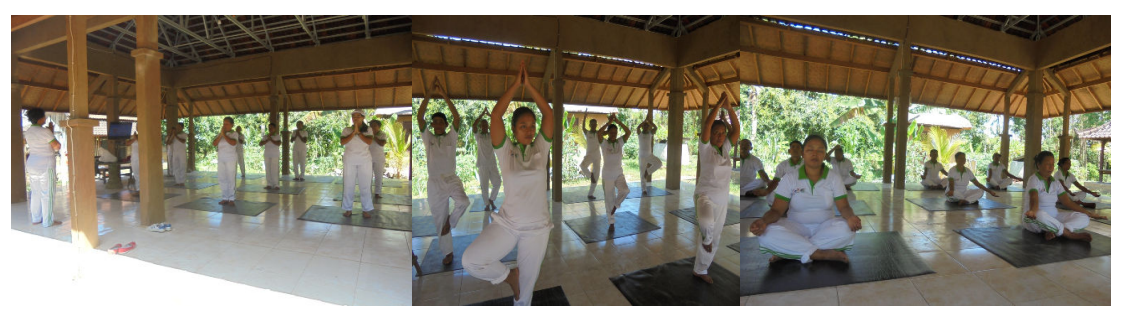

Figure 1. Yoga activities by persons with disabilities

Figure 1 regarding Praying before yoga begins so that speechless people will always feel the vibrations of the gods as a manifestation of God for the glory of his life. Then, one of the balance movements of the body so that the mentally and physically disabled people are balanced. Furthermore, is also centering of the mind through truly focused meditation so that it can get closer to perfection to be more beautiful in enjoying God's lila. After creating yoga exercises for the elderly and people with disabilities, one of the speech impaired residents danced the yoga exercise movement, so that the Yogi Nandini Gayatri Dance was born for the balance of nature and the residents who also danced it. The dancers are in Figure 2 along with the author as the creator of the dance and there are two hosts on the right and left at that time in the context of the dance show on Pertamina's Youtube.

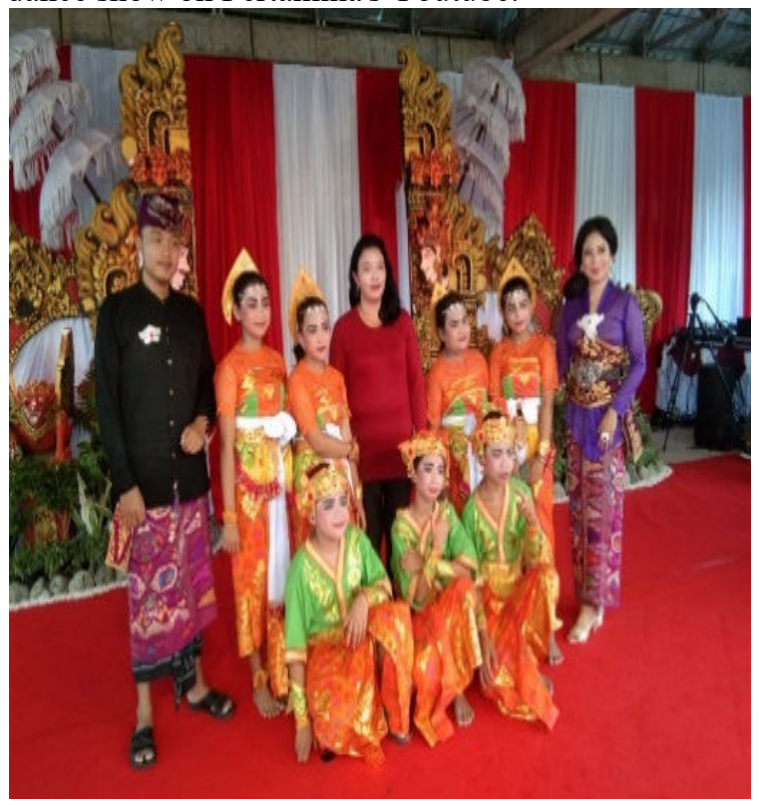

Figure 2. Yogi Nandini Gayatri Dance Crew 

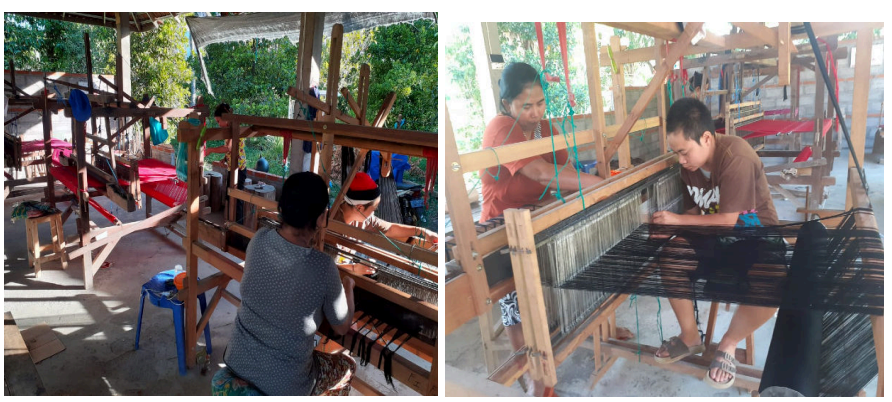

Figure 3. People with Disabilities Talk to Weave activities

In Figure 3, most of the women with disabilities are speech impaired, only those who are like men are actually women who put weaving threads and weave. There are several weaving tools that are used as income fields for women with speech impairments there. About 6 people usually weave in the Bengkala Speech Impaired Economic Zone. The weaving products are usually displayed in special buffets as a result of his work and some are sold in shops around Buleleng. The result has returned to become capital for the maker and is managed by the leader of the land, Mr. I Ketut Kanta.

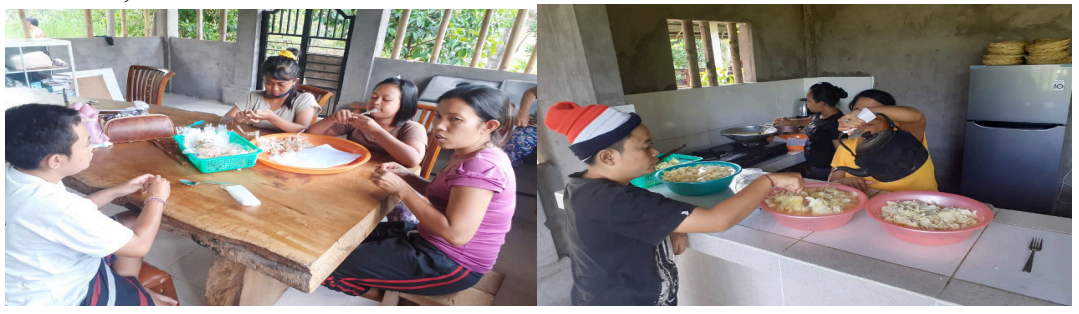

Figure 4. People with Disabilities processes Nuts and makes Cassava Chips

The picture above shows the empowerment of speech impaired women through making peas and cassava chips. Apart from that, they also made ladrang chips which can be sold in nearby stalls. Because for this type of snack or snack there are quite a lot of enthusiasts. To facilitate sales, now people with disabilities have made shops to sell their wares, so that they are even more enthusiastic about doing business.

- Impact of Empowerment for people with disabilities / speech impaired residents in Bengkala, Buleleng.

In connection with the empowerment of speech impaired people with various activities which are certainly in accordance with the hobby concerned, they are able to form a mindset and have high fighting power in competing with their surrounding friends. From the lazy women who are deaf and don't care about the development of the environment to being able to adjust to understand the progress of their friends so that they can produce enough work and money to support their lives. The impacts that affect the souls of the speech impaired people who are obtained during these activities include:

a) Adding scientific insights to the speech impaired and local residents

Before the arrival of Flipmas Indonesia to Bengkala Village, another agency came and had been assisted for agriculture and livestock. Each resident who was ready, was given several pigs and cows to be raised. And after being sold, sometimes they buy seeds back and some are not at all, so that the entire capital from the service given runs 
out. However, after the arrival of Flipmas Indonesia, which educated him to raise chickens, cows, and pigs, both women and men with speech disabilities were enthusiastic to manage the results and there was even one of the activities of the speech impaired person in the form of making incense, the results of which had entered into cooperatives and collaborated. with the local BUMDES so that the results can be seen clearly.

b) Making People with Disabilities / Talking Disabilities More Confident According to Their Hobby

With the programs offered for women with hearing impairment at that time, it certainly made him understand more about certain types of work that he could do and could also make money from these activities. Currently, feeling inferior, dumbfounded, sitting alone is rare in the environment with disabilities / speech impaired people, all the more enthusiastic to work to get wages from their work according to their respective hobbies. And the results are distributed to several areas in the village besides being entrusted to the local BUMDes.

c) People with Disabilities Talk More Independent and Its Impact on Normal Citizens

As a result, the women with hearing impairment become independent and dedicated and able to invite their friends to join in the effort so that the independence of the women with hearing impairment can be used as a sample or role model for other normal citizens in developing their ideas and ideas. So that other normal residents feel enthusiastic about working by seeing the situation of the speech impaired people who are more aggressive in looking for income. The independent efforts of the speech impaired residents there are an example for other villages in the vicinity. Due to the limited ability of the speech impaired residents, it turns out to be embarrassed, they are deterred from facing life's challenges for their progress.

\section{Conclusion}

Everyone always yearns for a life full of joy and zest for life. Behind the limitations of people with disabilities, it turns out that they have a sense of reaching for a brighter future by doing their best and it happens that Flipmas Indonesia with the help of Pertamina can give it a way to reach the spirit of its life again. Because if it is not directed, the people with disabilities or people with speech impairments will act inconsistently without any direction. Until it is known here that the uniqueness of Bengkala Village has been known to many people. In addition, the tips for empowering the speech impaired are not easy, it is necessary to understand the language of the speech impaired, a sense of compassion and a sense of brotherhood that is equal to others. The types of empowerment that have been done are yoga, massage, making ladrang chips, cassava chips and peas, besides that there are also weaving, making ingke, and making incense. So that the impact is very broad for residents with disabilities in the form of additional knowledge that makes them more confident, more independent and makes other normal residents more motivated and also takes the example of these people with disabilities / speech impaired. That is what the author can say, hopefully there are benefits. 


\section{Reference}

[1]. P. W. Renawati, "Eksistensi Warga Tuna Wicara Dalam Naskah Prasasti Desa Bengkala Kecamatan Kubutambahan Kabupaten Buleleng. (Perspektif Teologi Hindu)." Denpasar: Pascasarjana Institute Hindu Dharma, 2018.

[2]. I. M. D. Suteja. "Adaptasi Kehidupan Penyandang Tuli Bisu di Desa Bengkala Kecamatan Kubutambahan Kabupaten Buleleng (suatu Kajian Antropologi)." Denpasar : Jurusan Anropologi Fakultas Sastra Universitas Udayana, 1996.

[3]. Sejarah Singkat Desa Bengkala, dbengkala.blogspot.com.

[4]. S. N. Syobah, "Pemberdayaan Penyandang Disabilitas Di Provinsi Kalimantan Timur." J. Penelitian Ilmu Sosial dan Keagamaan Islam: Nuansa, vol. 15, no.2, 2018.

[5]. "Psikologi." Halodoc, https://www.halodoc.com/kesehatan/psikologi

[6]. F. G. Sim, "Integrating Women And Girlswith Disabilities Into Mainstream Vocational Training." Int. Labour Office, 1999.

[7]. "Disability and Health Inclusion Strategies." Cent. for Disease Control and Prevention, strategies.html

[8]. "Women and girls with disabilities." Dept. of Economic and Social Affairs Disability, https://www.un.org/development/desa/disabilities/issues/women-and-girls-withdisabilities.html.

[9]. Pudja, and T. R. Sudharta, "Manawa Dharma Sastra (Manu Dharmasastra) atau Weda Smrti." Surabaya: Paramitha, 2004. 